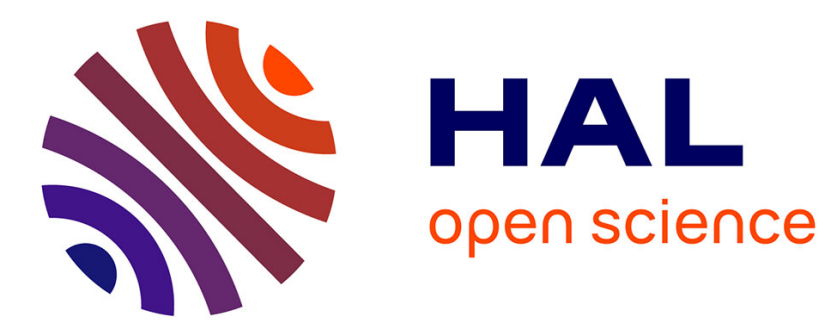

\title{
Conceptualizing Local and Regional Economic Development in the United States
}

David Valler, Andrew M Wood

\section{To cite this version:}

David Valler, Andrew M Wood. Conceptualizing Local and Regional Economic Development in the United States. Regional Studies, 2010, 44 (02), pp.139-151. 10.1080/00343400802378768 . hal00566756

\section{HAL Id: hal-00566756 https://hal.science/hal-00566756}

Submitted on 17 Feb 2011

HAL is a multi-disciplinary open access archive for the deposit and dissemination of scientific research documents, whether they are published or not. The documents may come from teaching and research institutions in France or abroad, or from public or private research centers.
L'archive ouverte pluridisciplinaire HAL, est destinée au dépôt et à la diffusion de documents scientifiques de niveau recherche, publiés ou non, émanant des établissements d'enseignement et de recherche français ou étrangers, des laboratoires publics ou privés. 


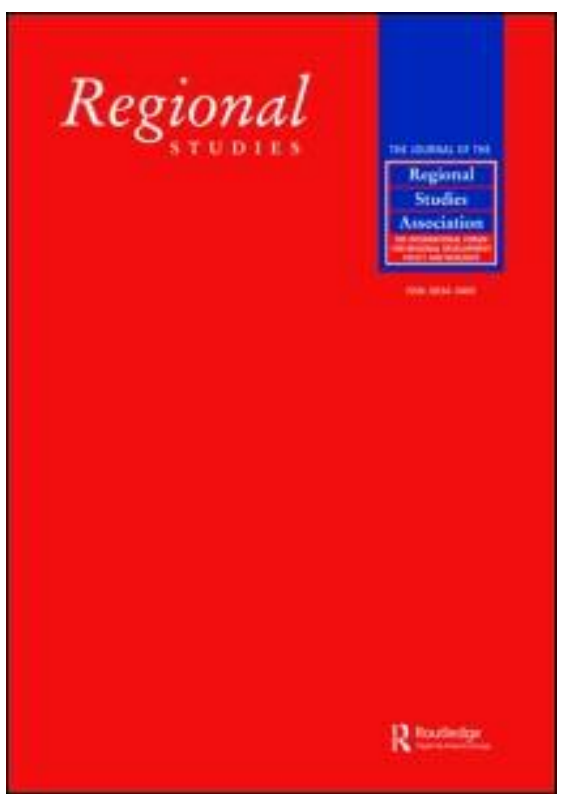

Conceptualizing Local and Regional Economic Development in the United States

\begin{tabular}{|r|l|}
\hline Journal: & Regional Studies \\
\hline Manuscript ID: & CRES-2007-0271.R1 \\
\hline Manuscript Type: & Main Section \\
\hline JEL codes: & $\begin{array}{l}\text { O51 - U.S.|Canada < O5 - Economywide Country Studies < O - } \\
\text { Economic Development, Technological Change, and Growth, P16 - } \\
\text { Systems }\end{array}$ \\
\hline Keywords: & Local and Regional Economic Development, Regulation Theory, USA \\
\hline
\end{tabular}

\section{今 ScholaroNE" \\ Manuscript Central}


Conceptualizing Local and Regional Economic Development in the United States

\author{
Dave Valler \\ Oxford Brookes University \\ Department of Planning \\ Oxford Brookes University \\ Gipsy Lane Campus \\ Headington \\ Oxford OX3 0BP \\ UK \\ dvaller@brookes.ac.uk \\ AND \\ Andrew Wood \\ University of Kentucky \\ Department of Geography \\ University of Kentucky \\ 1457 Patterson Office Tower \\ Lexington, Kentucky \\ 40506-0027 \\ USA \\ andrew.wood@uky.edu
}

First received: September 2007

Accepted: May 2008 
Conceptualizing Local and Regional Economic Development in the United States

\begin{abstract}
Contemporary literature on local and regional economic development (LRED) in the United States is predominantly empirical and pragmatic, focusing on the conduct and efficacy of economic development policy. While this work is valuable in evaluating the detailed operation of LRED activity, the broader conceptual foundations which underlay economic development practice have been underplayed. We reflect on research and writing around LRED in the U.S. and address some key conceptual and theoretical limitations. We call for a stronger focus on contextualization and set out a theoretical approach grounded in regulationist insights which offers significant advances in theorizing U.S. LRED.
\end{abstract}

Key Words: Local and Regional Economic Development; Regulation Theory; United States

JEL Classifications: R58 - Regional Development Policy; B52 - Institutional; Evolutionary; O18 - Regional, Urban, and Rural Analyses; P16 - Political Economy

Conceptualiser le développement local et régional économique aux Etats-Unis.

Valler \& Wood

http://mc.manuscriptcentral.com/cres Email: regional.studies@newcastle.ac.uk 
La documentation contemporaine sur le développement local et régional économique (DLRE) aux Etats-Unis est dans une large mesure empirique et pragmatique, portant sur la conduite et l'efficacité de la politique de développement économique. Alors que ce travail s'avère précieux dans l'évaluation du fonctionnement de l'activité DLRE, les fondements conceptuels plus larges qui étayent le développement économique en pratique ont été minimisés. On considère la recherche et la documentation à propos du DLRE aux Etats-Unis et aborde quelques-unes des limites conceptuelles et théoriques. On réclame que l'on mette l'accent plutôt sur le contexte et on établit une façon théorique fondée sur des aperçus réglementaires qui fournit des progrès non-négligeables quant à la théorisation du DLRE aux E-U.

Développement Local et Régional Economique / Théorie de réglementation / Etats-Unis

Classement JEL: R58; B52; O18; P16

\title{
Konzeptualisierung der lokalen und regionalen Wirtschaftsentwicklung in den USA
}

Dave Valler and Andrew Wood

\begin{abstract}
Die aktuelle Literatur über lokale und regionale Wirtschaftsentwicklung in den USA ist vorherrschend empirischer und pragmatischer Natur, wobei der Schwerpunkt auf der Führung und Wirksamkeit der Wirtschaftsentwicklungspolitik liegt. Diese Arbeit ist zwar eine wichtige Hilfe bei der Bewertung der detaillierten Funktionsweise der Aktivitäten im Bereich der lokalen und regionalen Wirtschaftsentwicklung, doch die breiteren konzeptuellen Grundlagen für die Praxis der Wirtschaftsentwicklung werden dabei vernachlässigt. Wir untersuchen die Forschung und Literatur über lokale und regionale Wirtschaftsentwicklung in den USA und befassen uns mit einigen wichtigen konzeptuellen und theoretischen Beschränkungen. Wir argumentieren für eine stärkere Betonung der Kontextualisierung und entwickeln einen theoretischen Ansatz, der auf regulationistischen Erkenntnissen aufbaut und bei der Theoretisierung der lokalen und regionalen Wirtschaftsentwicklung in den USA signifikante Fortschritte ermöglicht.
\end{abstract}

Key Words:

Lokale und regionale Wirtschaftsentwicklung

Regulationstheorie

USA 
JEL Classifications: R58 - Regional Development Policy; B52 - Institutional; Evolutionary; 018 - Regional, Urban, and Rural Analyses; P16 - Political Economy

\title{
Conceptualizar el desarrollo económico local y regional de los Estados Unidos
}

Dave Valler and Andrew Wood

\begin{abstract}
La literatura contemporánea sobre el desarrollo económico local y regional (DELR) en los Estados Unidos es predominantemente empírica y pragmática y se centra en la conducta y la eficacia de la política de desarrollo económico. Si bien este trabajo es valioso a la hora de evaluar la operación detallada de las actividades del DELR, los cimientos conceptuales más amplios que subyacen en las prácticas del desarrollo económico están mal representados. Analizamos los estudios y la literatura sobre el DELR en los EE.UU. y exponemos algunas limitaciones conceptuales y teoréticas principales. Es necesario prestar más atención a la contextualización y establecer un enfoque teórico basado en las perspectivas regulatorias que ofrecen ventajas significativas en la teorización del DELR de los EE.UU.
\end{abstract}

Key Words:

Desarrollo económico local y regional

Teoría regulatoria

Estados Unidos

JEL Classifications: R58 - Regional Development Policy; B52 - Institutional; Evolutionary; O18 - Regional, Urban, and Rural Analyses; P16 - Political Economy

1. Introduction

Fifteen years ago, in an influential paper in Urban Geography Susan CLARKE (1993)

highlighted a growing concern and discomfort with the study of local economic

http://mc.manuscriptcentral.com/cres 4 Email: regional.studies@newcastle.ac.uk 
development activity in the United States. It was apparent that work in the field was “informative but often uncritical and with little theoretical grounding" (1993: 78), and that opportunities to exploit a distinctive window into fundamental theoretical questions were being substantially missed. Clearly, major changes were underway in the economy and the state which would have the most profound implications for the nature and practice of economic development. Transformations in economic production, global competitiveness, information and communications technologies, state-market relations, welfare, central and local governance, and public-private relationships, to name just some of the more influential themes, could hardly avoid significant impacts on sub-national economic development activities. Indeed, change was already well underway with localities increasingly being seen as pivotal sites of competitiveness in a new global economy, and with the concomitant rise of entrepreneurialism in U.S. cities and regions (EISINGER 1988; HARVEY, 1989). In this context a central task was to understand and interpret such changes, and thereby provide convincing foundations for future policy. As CLARKE describes, a number of serious questions faced academics and policy-makers in the field, including "...most basically, what is the meaning of these current shifts from national to subnational initiatives in development policy?" (1993: 87).

This would seem, on the face of it, to present a straightforward rallying cry for a broader contextualization of economic development activity, and in particular the formulation of a more comprehensive and wide-ranging political-economy of economic development. Yet to date there is little evidence of a serious or sustained effort to establish such a framework. Rather, authors have continued to decry a 'myopic tunnel vision approach' 
(IMMERGUT, 1992, quoted in WILSON, 1999: 5) and a 'narrow evidentiary base' which omits 'critical variables and dynamics' (CLARKE, 2001: 320; REESE and ROSENFELD, 2001), often reinforcing the view of WIEWEL et al (1993: 94) that we have 'little in the way of an integrated theoretical framework' which might lend coherence to the analysis of U.S. local and regional economic development (LRED).

In this paper we reflect on the nature of research and writing around LRED in the U.S.. We argue that the literature is predominantly empirical and pragmatic in nature, focusing on the conduct of economic development policy and the relative efficacy of different policy choices. Though this work is enormously valuable in understanding and evaluating the detailed operation of LRED activity, the broader conceptual foundations which underlay economic development practice and its place in contemporary politicaleconomic analysis have been comparatively underplayed. We address some of the key conceptual and theoretical limitations and, in calling for further reflective work that focuses on conceptualizing the policies and practices of economic development, we argue for a stronger contextualization of LRED activity in the U.S.. We then set out a theoretical approach grounded in regulationist insights, which in our view offers significant advances in establishing a comprehensive and rigorous theorization of U.S. LRED.

Before we embark on such a project, however, a brief note of caution. Plainly, any attempt to establish such a broad commentary is, by its very nature, an imprecise task. For a start, delineating the field of local and regional (or for that matter 'neighbourhood', 
'local', 'regional', 'state', ‘community', 'urban', 'metropolitan') economic development is problematical. Clearly it is difficult to define any obvious boundaries around the LRED literature, not least given the more flexible and holistic approaches to such activity which have developed in recent years. Also, a vast amount of important work across politics, geography, sociology, economics, law, urban studies and a number of other disciplines is influential in the field, even if not ostensibly directed at local and regional economic development per se. As a result our discussion is necessarily selective and we recognize that comments on the field as a whole must remain somewhat impressionistic, but this seems inevitable given the diversity and potential scale of the field. Given these complexities we adopt a pragmatic focus on 'local and regional economic development' in the hope that this can incorporate distinctly urban, metropolitan, state and other economic development literatures. We hope, however, that some broad commentary can assist in distilling key characteristics, and in prompting further discussion.

2. The place of theory in the U.S. economic development literature

The question of how best to develop and deploy theory in the U.S. economic development literature has troubled authors for some time. While on one hand several contributions have bemoaned an apparent lack of a formal or convincing theory of local development (see for example CLARKE, 2001; FASENFEST et al 1997; KIRBY, 1985; 
BEAUMONT and HOVEY, 1985), others have highlighted the confusion engendered by a multiplicity of very specific and narrow theoretical frameworks. Overall there is concern that theoretical approaches in LRED have been variously unconvincing, incomplete, or inappropriate (see, for example, CLARKE, 1993; 2001; FASENFEST et al 1997; REESE and ROSENFELD, 2001; WIEWEL et al, 1993; WILSON, 1999). For WIEWEL et al previous theoretical contributions in the field have been unable to grapple effectively with the range of tasks required, such that economic development theory 'on the whole... does not do well' (WIEWEL et al, 1993: 94). In summarizing some of the limitations of extant theory WILSON notes, albeit somewhat ambiguously:

\begin{abstract}
"Perhaps the most serious weakness of these models is the inadequate conceptualization of state economic development with respect to the lack of substantiated theory. Ironically, researchers are not hesitant in introducing new theories; there is an ample supply in the literature. What concerns scholars... is that in trying to understand the economic development process we are not confronted by a lack of a theory, but instead a multiplicity of theoretical models. Yet, in many cases, the theory underlying empirical examinations of the effects of development policies is assumed, or is not made explicit" (1999: 4)
\end{abstract}

In turn a variety of contributors have noted the potential impacts of such theoretical shortcomings on policy development and implementation, as well as on the prospects for 
a comprehensive theoretical account of local economies and their dynamics (WIEWEL et al, 1993). REESE and FASENFEST (1997: 196), for example, argue that theoretical under-development has been associated with piecemeal and incremental policy, overgeneralized goals and objectives, highly unsophisticated strategy, and a very limited understanding of the causal mechanisms which link policy formation, implementation and outcomes. Similarly, WILSON (1999), drawing on IMMERGUT (1992), argues:

\begin{abstract}
This myopic tunnel-vision approach to state activism in economic development has fragmented initiatives resulting in diluted policy content (KING, 1992), in addition to frustrating scholars attempts to read wholesale shifts in policy direction (IMMERGUT, 1992, quoted in WILSON, 1999: 5)
\end{abstract}

\begin{abstract}
Unravelling the reasons for such theoretical limitations is a complicated task, and we restrict our comments here to some initial speculation around a number of potentially contributory factors. First, we might note the tendency in the U.S. LRED literature towards instrumental and pragmatic concerns which results in a rather indirect engagement with more abstract or contextual questions. To a large extent it would appear that the overwhelming concern in the U.S. literature has been to advance the practice of economic development (see BINGHAM and MIER, 1993: ix; MIER and FITZGERALD, 1991), and that authors have been convinced by the argument that "...the profound meanings of local economic development policies rest in the distributional dimensions and substantive effects of these policies, the areas least understood by scholars and
\end{abstract} http://mc.manuscriptcentral.com/cres 99mail: regional.studies@newcastle.ac.uk 
practitioners" (CLARKE, 1993: 88). In many ways this chimes with a long-established pragmatism in American philosophy, politics and culture which continues to resonate across a variety of spheres. As CRUNDEN (1996: 146) sets out in reviewing the emergence of this distinctively American philosophy in the late $19^{\text {th }}$ and early $20^{\text {th }}$ centuries, pragmatism:

... argued against abstractions that had no results; it argued against an ethics that did not affect ordinary lives; it assumed that solving daily problems was more important than achieving abstract truths; it tried to tell people that what everyone thought and did was important, and that Americans did not need extensive technical philosophical training to lead meaningful lives. Europeans were entangled in class and metaphysical systems that were inappropriate for American democracy; and the pragmatists were trying to achieve a means of procedure which eliminated them.

In this context a characteristic feature of social scientific enquiry in the U.S. has been an orientation to the concrete, and we would argue that to a large extent this has been reflected in the literature around LRED. Certainly the economic development literature has emerged predominantly from pragmatic concerns for declining urban and rural communities and in the search for social justice (WIEWEL et al, 1993: 95), and much theoretical and empirical work in the U.S. has been dedicated to advancing the practice of LRED in the U.S. per se (MIER and FITZGERALD, 1991: 268-69). The tendency has 
been to develop 'instrumental' theory and 'guidance for action', often regarding the usefulness or otherwise of individual initiatives (WIEWEL et al, 1993: 93), and to turn directly to the sphere of practice for theoretical guidance and inspiration. The outcome is a rather fragmented literature which has lacked a clear sense of overall direction, and often militated against more abstract and more comprehensive theoretical accounts which might fully contextualize LRED activity. The implications of this concern for the concrete have been identified in another context by Richard LEHNE (2006), writing on the literature around business-government relations in the U.S.:

Most Americans evaluate political issues concretely. They are more concerned about immediate problems than about the ideological implications of potential policies. The relationship between governments and business is rarely addressed directly in the United States. It is usually fought out, instead, on the margins of such topics as working conditions, environmental costs, campaign contributions and health care costs. Implicit in such disputes is an intense rivalry over the influence of business and non-business groups in society. Various scholars address this rivalry by presenting models that express their understanding of what the relationship among government, business and non-business groups in the society is or should be (LEHNE, 2006: 31)

A corollary of this more concrete focus is the nature of the urban politics literature in the U.S.. Here pluralist models, for example, have established an 'empirical descriptive' 
approach to the autonomous political realm, together with normative and presciptive implications, rather than attempt to interrogate the structural or class foundations for such a political form. Similarly, growth machine theory and regime theories, which have assumed a dominant position in urban political analyses, have a limited theoretical focus and have been criticized as underplaying broader structural features which would be key to any comprehensive explanation of local political forms and dynamics (DAVIES, 2002: 2; JESSOP et al; 1999).

A second contributory factor to the pattern of theoretical development derives from the real material conditions of the U.S. political economy, and not least the remarkable disorganization and fragmentation of American politics and government (GORDON, 1998). Of course, the U.S. system of federal government effectively fragments power among different levels of the state and parts of the state apparatus. But additionally, national political institutions have been largely unable to exert long-term strategic leadership in the domestic arena. As GORDON argues:

Political disorganization is rooted in constitutional design. The American state has always been premised on practical and intellectual doubts about the scope and reach of national politics. A few core concerns made national government necessary; a multitude of regional interests ensured that, especially in domestic economic affairs, such government would have little power (GORDON, 1998: 31). 
Further, it is apparent that U.S. political culture and institutions have effectively 'discouraged substantial programmatic debate' (GORDON, 1998: 31), with concomitant impacts on the nature of policy development and implementation. In this context it might not be wholly surprising that theoretical accounts have to some extent mirrored such fragmentation and lack of cohesion. Added to this the 'sheer scale and diversity of industrial development' across the continental U.S. (GORDON, 1998: 35) further problematizes attempts at comprehensive and integrated theorization.

A third factor here is the notable stability of economic development activities in recent years. Despite radical changes in the political-economic context for LRED policy, and claims of a significant re-ordering of policy and institutional responses at local, regional and other scales, REESE and ROSENFELD (2004) highlight the limits of change in the day-to-day practice of economic development activity on the ground. Thus 'a relatively traditional set of policies is becoming institutionalized and provides a common framework for the practice of economic development' (2004: 286), and we might at least tentatively suggest that this apparent stasis has not encouraged attempts at comprehensive theoretical analysis and development.

In the light of ongoing theoretical shortcomings a number of contributors have called for further development which might transcend the current impasse. Yet the limited progress in this sphere to date suggests that the task of 'theorizing U.S. LRED' does not lend itself to a straightforward resolution. Indeed, we might note the lack of any clear agreement over the central objectives for a 'theory of economic development'. For CLARKE 
(2001), for example, the emphasis is on establishing a 'causal theory of local economic policy making' which can explain the overall trajectory of economic development activity:

If we are aiming for some ever grander causal theory of local economic development policy making, then the weak and widely varying coefficients produced by mostly incommensurable quantitative studies are important. They signify how far we are from that goal-mis-specification is indeed worth worrying about to the extent that it obscures causality. But if we seek to explain, at best, clusters or classes of events, problems, or dynamics, we need analytic frameworks to help us understand those patterns (CLARKE, 2001: 321)

\begin{abstract}
Alternatively, WIEWEL et al (1993: 93) identify a number of requirements for a convincing theory of economic development which in their view needs to be simultaneously contextual and agential, explanatory and instrumental, positive and normative:
\end{abstract}

First, the theory should concern itself with the neighborhood economy and its linkages. It should deal explicitly with economic variables and tell us something useful about them... The theory must also be socio-political because the activity with which it is concerned is rooted in a particular form of social institution and its practitioners act explicitly within a 
political framework... The actual experience of practitioners suggests three additional, more abstract requirements for a theory. First, the theory must be instrumental, that is it should provide guidance for action rather than simply a positive explanation of how things behave. Second, it should also be normative, that is, it must embody a set of objectives and arguments for their realization... Third, a neighborhood economic development theory requires a positive understanding of the contextual world in which the action that it deals with will be played out. This term describes the kind of understanding of relationships and interactions that is necessary for effective action.

This is, of course, ambitious. Indeed WIEWEL et al (1993: 84) admit the possibility that 'the formulation of one single theory would... be of such an abstract character as to be useless: perhaps these criteria need to be applied to a set of inter-related theories'. Also, they recognize that 'a broadly accepted theory of community economic development is a long way off' (1993: 95), and that despite the existence of some elements which might contribute to such a theory, formidable obstacles remain. In this context they turn to the sphere of practice and set out a number of normative themes upon which successful economic development programs might be constructed. Similarly, BINGHAM and MIER (1993: ix) set out with positive intent:

The pivotal assumption behind this book, however, is that research should and can lead to general statements about economic development. This 
assumption implies that the behaviour of firms and the development process can be explained and predicted in terms of general laws established by observation.

Yet they quickly retreat to the admission that the field of economic development is 'a very confusing place indeed' (ix), drawing on multiple theoretical frameworks across numerous disciplines, to the point at which 'we recognize the folly of our initial goal... that of articulating a synthetic theory of local economic development' (xv). Instead they turn to a series of metaphors (i.e. economic development as: 'problem solving'; 'running a business'; 'building a growth machine'; 'preserving nature and place'; 'releasing human potential'; 'exerting leadership'; and 'seeking social justice') which can produce 'distinctive yet partial' (xv) insights into particular meanings of economic development activity.

In our view, however, a shift to analytical methods based around 'metaphors of economic development' provides very little guidance to inform systematic analysis. It undermines attempts to engage with the overall meaning of LRED activity as it develops over time and space, and is limited in terms of the interrelationships between diverse areas of activity. Also it provides no clear theoretical foundation upon which to construct explanatory and evaluative judgements. We argue instead for an approach based in regulation theory, a conceptual framework introduced in France in the 1970s which has subsequently come to exert considerable influence in studies of the state and social and economic policy more generally across a wide variety of contexts, both in Europe and in 
the U.S.. This theoretical stance can assist significantly in locating LRED activity in a broader political-economic context, in explaining the evolution of LRED and its distinctive institutional and policy forms with reference to the evolution of the political economy and the state, and in establishing a framework within which to evaluate the scale, nature and overall contribution of LRED activity. Extending such insights might also inform deliberations over the development of future LRED policy and its role in addressing contemporary and future challenges (cf. PRIOR, 2005). In these senses a regulationist approach can provide a much stronger and more sophisticated contextualization of LRED, and in turn offer significant potential to advance the overall approach to theorization in U.S. LRED.

3. Contextualizing U.S. economic development: A regulationist contribution?

\section{The Regulation Approach}

By now the contours of the original regulationist account are well known. Beginning from an assertion of the contradictory and crisis-prone nature of capitalist society, regulation theory emphasizes the social norms, mechanisms and institutions which may come together to derive a contingent and necessarily temporary stability in capitalist accumulation processes (AGLIETTA, 1979, 1998; BOYER, 1990; JESSOP, 1990, 1997; LIPIETZ, 1987; PECK and TICKELL, 1992, 1995). This establishes a distinctive 
theoretical starting point in which the economy tends neither to an automatic equilibrium as in conventional economics, or to an inevitable breakdown as in Marxist theory (FRIEDMAN, 2000: 61). Rather, an 'accumulation system', or characteristic set of relationships between production and consumption, emerges to a position of dominance within an economic arena and may come to be sustained in the medium term by a 'mode of regulation' (variously 'mode of social regulation', 'social mode of economic regulation') or collection of social and institutional supports which together provide a degree of coherence and stability to an overall 'regime of accumulation'. Such stability is necessarily temporary, acting only to mute or disguise both the inherent contradictions of capitalist production and the tensions which necessarily exist within institutional forms. Each regime of accumulation thus contains the seeds of its own destruction, beyond which capitalist production and regulation must be thoroughly transformed to secure its future survival. Capitalism therefore proceeds historically through periods of stability and growth, when accumulation and reproduction are relatively steady, and periods of crisis, when the conditions for capitalist social reproduction are found wanting.

Within this overarching and essentially methodological framework (see BOYER, 1990; JESSOP, 1990; GOODWIN and PAINTER, 1996), regulationists have offered specific accounts of political-economic restructuring, most notably around the emergence and consolidation of Fordism (AGLIETTA, 1979) and the putative transition to post-Fordism (LIPIETZ, 1987). Much of this early literature is well known and there is no need to rehearse it here. Additionally, a wide range of authors have deployed regulationist insights to position and inform their analyses across a variety of spheres, including, for 
example, U.K. urban politics (GOODWIN, DUNCAN and HALFORD, 1993), U.K. urban and regional development (PECK and TICKELL, 1992; 1995), U.S. urban policy (FLORIDA and JONAS, 1991), and U.S. housing (FLORIDA and FELDMAN, 1988). Such accounts have achieved notable advances in these various spheres by contextualizing particular policy fields in a broader political-economic and institutional arena, and making critical connections between economic, social, political, cultural and institutional practices. Regulationists have also elaborated on a number of apparent weaknesses in initial formulations of the regulationist approach, most notably in responding to accusations of structuralism and economic determinism. Hence a number of authors have recognized explicitly the contingency inherent in regulationist accounts, and stressed a concern for agency and practice (GOODWIN, 2001; JENSON, 1989; 1990; 1993; JESSOP, 1997; PAINTER, 1997; PAINTER and GOODWIN, 1995) as well as emphasizing political and institutional dynamics (PURCELL, 2002). Yet the central theoretical and methodological contribution of regulation theory has proved notably robust, and it might be argued that as "a perspective and form of analysis" (GOODWIN and PAINTER, 1996) regulation theory has come to exert significant influence.

From a regulationist standpoint contemporary local and regional economic development activity is best viewed within the context of overall patterns of institutional change and policy experimentation directed towards the establishment of some form of post-Fordist mode of regulation (GOODWIN, 2001: 74). On the one hand the structures and practices of economic development activity at sub-national scales will be critically influenced by broader processes of restructuring in state-market relations, innovation and competition 
systems, formal regulatory frameworks, governance structures, patterns of social organization, political and ideological commitments, and economic, social and cultural policy. Clearly national policy shifts will impact directly on institutional forms and policy development and implementation in localities and regions. Yet this cannot in any sense be seen as a simplistic or undifferentiated projection of national changes onto localities. Rather, regulatory practices operating at a variety of scales necessarily find expression locally, both reflecting the pre-existing character of uneven development, and being actively constituted locally. As GOODWIN et al (1993: 69) point out,

\begin{abstract}
Economic, social and political experiences of regulation vary between places within a country, often significantly so... differentiated spaces of regulation arise not only because these experiences reflect localized conditions of production and consumption, and local constellations of social forces and cultural practices, but also because local agencies are often the very medium through which regulatory practices are interpreted and ultimately delivered.
\end{abstract}

Additionally, of course, localities and regions come to play different roles, with different degrees of success or failure, within overall national regimes of accumulation. For it is apparent that regions and localities are characterized by distinctive accumulationregulation couplings and will be inserted differentially into both wider spatial divisions of labour and regulatory structures (see PECK and TICKELL, 1992; 1995). As PECK and TICKELL point out (1992: 352) "some regional economies... will be favoured by 
national accumulation strategies while others will not". But it is also clear that different regulatory functions operate at different spatial scales (GOODWIN, 2001: 78; PECK and TICKELL, 1992: 352), and that a whole variety of social, cultural and institutional forms contribute to distinctively local or regional regulatory effects. PECK and TICKELL, for example, highlight the potential role of local growth coalitions, inter-firm networks, labour market structures and institutions, housing markets, venture capital arrangements, forms of local governance, local economic policies and relations in civil society (1992: 353). As a result economic development activity will also reflect the search for a 'regulatory fix' at the local or regional scale, as localities with distinctive economic, social, political, cultural and institutional histories seek to position themselves within the context of a broader accumulation strategy (GOODWIN, 2001: 78).

Overall, then, regulation theory promises significant advances both in contextualizing LRED activities broadly within the search for a resolution to the crisis Fordism and the experimentation over new post-Fordist regulatory forms, and in approaching the diverse mechanisms and forms of regulation operating in particular (sub-national) spatial contexts. This has important theoretical implications which we explore further in the following discussion.

Explaining and Evaluating Local and Regional Economic Development in the United States: Regulationist Insights 
A regulationist approach offers distinctive and potentially powerful insights into U.S. LRED in two key areas: Firstly, in developing an explanation of the evolving nature of sub-national economic development activity founded in the overall restructuring of the U.S. state and political-economy; and secondly in developing a more sophisticated approach to the evaluation of economic development activity as a whole, sensitive both to the multiplicity of roles that such policy can play in diverse contexts, and to the overall limits of evaluation per se. We develop each of these themes in turn.

\section{Explanation}

A useful corrective to the original regulationist account is provided by GOODWIN (2001) and GOODWIN and PAINTER (1995: 18-23) in their critique of the 'mode of regulation' concept. Such a notion, they argue, substantially downplays the emergent nature of regulatory processes, as well as the empirical reality of ongoing change, conflict and upheaval in capitalist society. Rather than 'sharp breaks and radical discontinuities' (1995: 19) they stress a more fluid 'ebb and flow' of regulatory processes across time and space (1995: 21), accompanied by more or less successful regulatory effects. This, in turn, elevates a concern for strategy and practice in the ongoing reproduction of capitalist society, rather than a more static reading of structure and form within a particular mode of regulation. In place of the supposed structural demands of particular accumulation regimes, therefore, regulatory processes are the product of material and discursive practices' themselves 'conditioned by social and political institutions' (GOODWIN and PAINTER, 1995: 21). In this context regulation theory requires allied theories (of the 
state, governance etc), together with detailed empirical and historical research to illuminate processes of change within particular institutions and political forms, rather than explaining change as the straightforward expression of capitalist structural requirements (see GOODWIN, 2001: 85-6). In this context neo-Gramscian state theoretical insights have been deployed to approach processes of state restructuring, through analysis of 'the political forces and regulatory practices and discourses' which become hegemonic through particular state projects and societal paradigms (GOODWIN, 2001: 85-6). Explaining change in the state thus requires an emphasis on practice and strategy in the achievement of hegemony, and particularly on exploring how political, intellectual and moral leadership is:
"mediated through a complex ensemble of institutions, organizations and forces operating within, orientated toward or located at a distance from the juridico-political state apparatus" (JESSOP, 1997: p. 52; quoted in GOODWIN 2001: 85).

\begin{abstract}
In what ways might such a framework inform our understanding of the dynamics of the U.S. state and hence the restructuring of U.S. LRED? In developing this for our present purposes we can draw upon a brilliant historical synthesis by Robert BRENNER (2007), which situates the evolution of U.S. politics and political strategy within the context of underlying shifts in the balance of class forces, structural movements in the American polity, and changes in the pattern of capital accumulation. Here the historic structural weaknesses of organized labour, in particular with regard to its problematical relationship
\end{abstract}


with the Democratic Party and its underdevelopment in the South, provide the basis for a distinctive political-economic trajectory in the U.S.. Despite the 'unprecedented explosion' of working class power in the 1930s and the influence of liberal reformism throughout the postwar era, the U.S. polity never seriously challenged corporate hegemony. This reflected the continual subordination and emasculation of organized labour in the U.S. which, along with other leading social movements, was largely 'domesticated' within a Democratic Party which itself prioritized capitalist profitability. As a result the 'Great Society' version of the Keynesian welfare state which developed in the U.S. became a form of 'growth liberalism', predicated upon the effective incorporation of organized labour and other social pressures within the social compact, and critically underwritten by corporate expansion. However, this arrangement was wholly dependent on sustained economic growth and profitability. Once this was challenged by economic slowdown in the 1960 s and subsequent stagflation into the 1970 s conditions were ripe for the breakdown of the liberal welfare state system. Here, as BRENNER argues, it was the debilitated state of the labour movement in the U.S. which crucially enabled the onslaught of the corporations in the drive to restore profitability. This formed part of a broad agenda designed to undermine the whole foundation of the welfare state, and would be dependent on the construction of a broad base of support:

With the onset of the long downturn, and the political vacuum left by liberalism's collapse, American corporations became the driving force that would shift the polity to the right. But the growing success of the business agenda within the halls of government is inexplicable purely in terms of 
corporate mobilization. Its scope depended on the ability of the Republicans to develop a new hegemonic project that would replace 'Great Society' liberalism and offer an alternative model to significant sections of the working class (BRENNER 2007: 44-5).

For BRENNER, this proceeded in three overlapping phases. First, Nixon's 'southern strategy' in the 1960s began to destabilize Democratic support amongst the white working class, albeit within the context of continuing federal identification with 'Great Society' liberal reform, and accepting the persistence of the electoral strength of the Democrats overall. Second, economic crisis in the 1970s, together with increasing concern over federal taxation and spending, facilitated an anti-statist Republican ideology which resonated with a weakened and demoralized working class. The resulting 'tax revolt' forged a 'cross-class alliance with business' (2007:46), setting the context for the effective naturalization of the business agenda under Reagan. Third, the Republican Party forged a 'historic increase' in its national power by mobilizing right-wing business interests and social conservatives in the emergent and increasingly dynamic South, where strong free market and anti-statist sentiment provided a propitious environment for the already staunchly pro-business Party. This gradually gave rise to the Republican's broad hegemonic project which could finally break fundamentally with the Great Society settlement:

The answer, as we have seen, was to look to the South, both as model and as electoral base, to construct an anti-statist individualist ideology founded 
on white supremacy, defence of the patriarchal family and Protestant fundamentalism. It was the Republican right's success in constructing this ideological formula, and in identifying the liberal state as a central threat to the racial status quo and 'traditional family values', that provided it with the wherewithal to contend for power on a brazenly pro-business programme. Its targets were the key aspects of the New Deal-Great Society settlement that no administration, Democrat or Republican, had so far dared to touch: Social Security, progressive taxation and (a good part of) the business regulatory regime, including the EPA [Environmental Protection Agency] and OSHA [Occupational Safety and Health Administration] (BRENNER 2007: 48)

The power of BRENNER's neo-Gramscian account derives from a critical interweaving of economic, social, political and cultural change, focusing on the dynamics of political strategy and moral and intellectual leadership within a distinctive institutional framework. It demonstrates that the course of political-economic strategy and state restructuring cannot be reduced to a simplistic unfolding of structural dynamics, for example through the exhaustion of Fordism and the natural emergence of a new regime (GOODWIN, 2001: 85). Rather, it avoids such economism by recognizing, as GOODWIN (2001: 86) suggests, that such a transformation "is narrated, manifested and resolved within the ideas, spaces and times of particular state projects and societal paradigms". 
Within this overarching hegemonic project the U.S. has operated to a large extent as the exemplar of neoliberalism. As the prototypical liberal market economy the U.S. has been at the forefront of deregulation, privatization, welfare state retrenchment, labour market flexibilization, business-oriented taxation reform and broader reorientation of economic and social policy to the perceived needs of the private sector (JESSOP, 2002: 260). This market-oriented restructuring might be seen as a composite strategy for competitiveness, incorporating several major strands of neoliberal reorganization, including, for example: cost reduction and increased flexibility in the labour market, a distinctive neoliberal and property-based approach to the expansion of the knowledge based economy, and the liberalization of finance capital. Each of these elements of a neoliberal accumulation strategy faces distinctive problematics and regulatory challenges, and is associated with particular forms of institutional and policy change. Yet what is clear is that the Republican hegemonic project has incorporated major changes in the state, governance and a wide range of economic, welfare, and regulatory policy which critically influence the form and nature of sub-national economic development policy in the U.S.. These include, inter alia: An overall commitment to welfare state retrenchment; federal government withdrawal from urban policy (HENDRICKSON, 2004); the effective restatement and fiscal reinforcement of the long-established decentralization of American politics, together with an extended devolution of responsibility for economic development (KANTOR, 2007); maintenance of the federal government's relatively marginal involvement in employment and job training policies (CAMPBELL and PEDERSEN, 2006); ongoing resistance to any serious attempt at coordinated industrial policy in favour of market, macroeconomic and overall regulatory controls (CAMPBELL 
and PEDERSEN, 2006: 16); and a free market approach to the knowledge based economy based in property rights, rather than explicit dirigiste industrial policy.

Clearly this is only a schematic listing. Yet it illustrates just some of the key policy spheres through which the overarching neo-liberal strategy has exerted the most profound influence on the evolution of LRED in the U.S. since the 1970s. In some instances local and regional responses may be substantially hemmed in or, indeed, wholly negated by national policy, though they may also reflect local economic and fiscal conditions, and cultural and political factors. Local social relations, organisational arrangements and patterns of political hegemony, for example, might alter the objectives and actions of local political coalitions, shift the tactics of economic development organisations, or engender conflict between federal and local government (see CLOKE and GOODWIN, 1992). In addition, policy developed at local or regional levels may work to exert influence at higher levels of government and then in turn impact on the evolution of subnational policy. However, in our view it is impossible to fully understand the nature, form and meaning of LRED activity without a clear sense of the overall national accumulation strategy set out above.

A brief example here is illustrative. KRINSKY (2007; see also KRINSKY and REESE, 2006) has recently demonstrated how workfare programs have been experienced differently across a number of U.S. cities as national welfare restructuring processes intersect with distinctive urban political dynamics such as labour market conditions, fiscal management arrangements, institutional rules, policy networks and urban regimes. 
New York City's initial experience with workfare in the mid-1990s, for instance, is distinct. Here Mayor Giuliani enacted the nation's most ambitious public sector-based workfare program in 1995 , one year prior to the passage of the Personal Responsibility and Work Opportunity Reconciliation Act (PRWORA), and significantly expanding an existing municipal workfare programme. This reflected particular fiscal and labour market conditions in the city, as budgetary difficulties forced the lay-off (under previous Mayor David Dinkin) of thousands of municipal workers who were then, in the context of high levels of unemployment and welfare dependency, largely replaced by welfare recipients on 'work experience programmes'. However, as KRINSKY (2007) illustrates in detail, the prosecution of public sector-based workfare policy was also critically dependent on the strength of the Mayor's office in the city's institutional system, the political capacity to manoeuvre effectively in the face of opposition to workfare, and the presence of partners committed to anti-welfarism within the hegemonic urban regime. New York City's early experience was thus distinguished by the widespread use of work experience program placements, in contrast to cases in Milwaukee and Los Angeles (KRINSKY, 2007). In Milwaukee an influential conservative policy network at the state level in Wisconsin effectively prevented the public sector from running workfare programmes in the city, where workfare placements were concentrated in the private sector; while in Los Angeles County oppositional unions were able to demand effective 'anti-displacement' controls on public sector workfare placements in the face of a weak executive board. 
Subsequently New York City's initial response gave way to a revised policy focus as unemployment fell and the city's finances stabilized. The public sector-based work programme was replaced by predominantly job-search activities and private labour forceattachment measures. However, KRINSKY (2007: 787-788) shows how the welfare reformers of Giuliani's administration were then able to 'jump scale' to join conservative think-tanks, foundations and the Federal Department of Health and Human Services, and thereby propagate New York City's 'full engagement model' which subsequently became part of federal law. In this sense workfare has a complex multi-scalar 'fix' between national, state and local scales, and it is clear that local workfare regimes have been cultivated to introduce, experiment and refine workfare strategies and to guide Federal reform (Jessop and Peck, 1999). Yet as Jessop and Peck (1999: 26) go on to argue: 'the decisive strategic context for this upsurge in state and local level welfare reform has been set by changing priorities, frameworks and incentives in federal policy'. In sum, further research is required to investigate the complex and multi-layered political, economic and cultural dynamics which shape the expression of workfare policy in particular places. For Krinsky (2007: 791-2):

The complex rescaling of policy in the wake of the FSA and PRWORA suggests, however, that comparisons among cities and states will have to grapple theoretically and methodologically with the nonindependence of cases. The interweaving of global players, such as bond-rating agencies and real estate barons; national-scale players, such as conservative think tanks, policy research institutions and academics, and welfare-to-work services companies; state-level actors such as 
state governments and suburban politicians; and local-level actors such as mayors, council members, other landowners and businesses, nonprofit service providers, and labor unions into policy networks around welfare reform means that their particular configurations will mediate, in different ways, the labormarket demands and fiscal-management demands of "those who control the levers of economic activity".

\section{Evaluation}

The past 20 years or so have witnessed the development of a substantial critique of evaluative work in U.S. LRED. As CLARKE and GAILE argued in 1992, efforts to evaluate local economic development policy had become 'a quagmire of good intentions and bad measures' (1992: 193), and a variety of contributions have since sought to change the bases for evaluative work. In general these have problematized traditional evaluative measures and methods, such as the focus on basic job creation/retention measures, and argued for a shift from narrow 'process' or 'formative' evaluation to a broader concern with the overall 'outcomes' and 'impacts' of policies (see, for example, BARTIK, 2002; BARTIK and BINGHAM, 1995; REESE and FASENFEST, 1997). This has also been associated with calls for a much wider range of criteria in evaluating LRED (REESE and FASENFEST, 1997; MOLOTCH, 1991), albeit accepting the added complexity which would inevitably arise. Additionally, a number of contributions have exposed the essentially value-laden nature of evaluative processes and judgements and the often implicit theoretical positions adopted in evaluative work. Yet despite this 
sustained period of attention there is little substantive basis upon which to frame judgements on some of the most basic questions regarding LRED. What counts as the 'success' or 'failure' of LRED in a locality or region, and why? Is the form of LRED in a place appropriate given the economic, social, political and cultural challenges being faced? Is the program of LRED sustainable? In our view the lack of clear guidance on these questions derives from the theoretical tendency to underplay both the broader context of economic and state restructuring and locally specific conditions within which economic development activities are situated, and within which their distinctive contributions are defined. In this context a regulationist approach can contribute significantly by informing the overall approach to the evaluation of U.S. LRED (see Valler, Wood and North, 2000 for related discussion).

Given the recent regulationist focus on ongoing regulatory processes outlined above, we can derive two very broad basic criteria upon which to construct evaluations of changing policy forms and institutional frameworks. These relate to the specific contributions of economic development activities in (i) managing ongoing crisis tendencies, and (ii) facilitating the reproduction of capitalist social relations. Clearly, this is not to suggest that individual economic development initiatives could in any way be evaluated in these abstract terms per se. Rather, LRED activity, operating in conjunction with an array of socio-political, institutional and cultural forces and processes, may come to play distinctive roles in the production of 'regulatory effects', which are themselves necessarily 'greater than, or qualitatively different from, the sum of individual effects' (PAINTER and GOODWIN, 1995: 335). Such effects are emergent properties of a social 
system and are inherently relational. They may incorporate specific political compromises, institutional forms, social expectations or fiscal and organisational arrangements, but it is important to note that regulatory effects do not emerge directly from these individual elements, but through critical interrelations amongst these and other forms, and may therefore be specified only in terms of the broader system.

In this context the starting point for understanding the 'meaning' of LRED activity is in defining the ways in which localities and regions come to find a degree of 'local economic integrity' (EISENSCHITZ and GOUGH, 1993) or 'structured coherence' (HARVEY, 1985) which temporarily stabilizes capitalist reproduction in particular times and places. This emerges from the combination of a wide variety of processes and practices operating at multiple scales, each with their own geographies and spatial structures, and will therefore vary spatially (Painter and Goodwin, 1995: 335). For HARVEY:

At the heart of that coherence lies a particular technological mix - understood not simply as hardware but also as organizational forms - and a dominant set of social relations. Together these define models of consumption as well as of the labour process. The coherence embraces the standard of living, the qualities and style of life, work satisfactions (or lack thereof), social hierarchies (authority structures in the workplace, status systems of consumption), and a whole set of sociological and psychological attitudes towards living, enjoying, entertaining and the like (1985: 140) 
This, in turn, suggests a distinctive approach to evaluation focusing on the extent to which, and the ways in which, LRED activity reinforces, reshapes or even undermines such coherence in particular places. Clearly, LRED activity may be implicated in many aspects of such coherence, ranging across production and consumption relations, social and political forms, and cultures and attitudes. Indeed LRED policy may come to play a variety of roles - simultaneously economic, political, institutional and cultural - in the construction of successful regulatory processes. HARVEY notes, for example:

innovation in production requires parallel innovation in consumption. It also requires innovation in social and physical infrastructures, spatial forms and broad social processes of reproduction. Innovation must extend to lifestyles, organizational forms (political, cultural and ideological as well as bureaucratic, commercial and administrative) and spatial configurations. (1985, pp. 126-7)

Yet, as we have outlined earlier, localities and regions are inserted differently in wider spatial divisions of labour and regulatory structures, and are characterized by distinctive social, cultural and institutional forms. Patterns of structured coherence therefore vary widely between places, and the contribution of LRED activities to such coherence will be similarly diverse. Evaluation must in turn be a more complex and comprehensive exercise than it has been to date. For if regulatory processes and effects are different in different places, evaluating the contribution of any one particular type of institution or activity across these places may involve measuring different things (see Valler, Wood 
and North, 2000). ). To return, briefly, to the case of workfare policy in New York City, we might reflect on the potential contributions of such a policy form in reinforcing a globally competitive, finance- and consumption-oriented regime. Here the key emphases of workfare, "flexibility for enterprise; geographic rescaling of economic and social intervention; replacement of entitlements with obligations on the part of citizens; and coalitional power-holding spanning governmental, civil society, and profit motivated actors" (Krinsky, 2006: 158) might perform roles in, for example, responding to fiscal crisis, channeling and containing political opposition, enhancing labour market flexibility, overcoming important institutional scleroses and managing social polarization. However, the key point is that the contribution of these diverse roles in establishing or reinforcing effective regulation in New York City specifically, will be distinctive. From this viewpoint it is only once we have defined the form of structured coherence in a place that we may distill the contribution of LRED activities in these particular arrangements. In turn the broadest evaluative questions around LRED activities - of their 'success' or 'failure', 'appropriateness' or 'sustainability' - can only be determined in context, that is with regard to their specific contributions to particular accumulation-regulation couplings in localities and regions. Evaluative work should therefore reflect the particularity of place and the distinctive character of regulation in any given case. In our view this promises a more rigorous and flexible starting point for a comprehensive evaluation of LRED activity, in contrast to more limited analyses of the specific goals, tasks or methods of any one particular institution or process. 


\section{Concluding Points}

In this paper we have argued for an approach which puts U.S. LRED in context. Exploiting the insights of a regulationist approach allows us to explain the evolution of LRED within the broader political-economic dynamics of capitalist development, to judge the distinctive contributions that LRED makes in a broader spatio-temporal 'fix', to locate it as a particular set of activities within a much broader policy context, and to more clearly understand the practical limitations of LRED policy. It provides an explicit theoretical framework within which to interrogate what might count as 'success' or 'failure' in this sphere, and the senses in which LRED policy might be come to be seen as 'sustainable'. Here a regulationist account recognizes that local and regional economic development policy is simultaneously economic, social, political, ideological and cultural, and its contributions to regulatory processes may operate in complex ways across these various spheres. Also, we would argue that in exposing critical aspects of contemporary political-economic dynamics, it can prove extremely valuable in the design and implementation of future policy.

In calling for a deeper engagement with the conceptualization of LRED we recognize that research and writing in the field would become less clearly targeted on straightforward measures of program outputs. The potential of individual LRED schemes for job creation, value for money, investment attraction and the like are best measured through alternative theoretical frameworks and methodological approaches. Yet such analyses lack the 
capacity to understand and interpret the overall contribution of LRED within particular political-economic contexts. In this sense the 'profound meanings' of LRED policies not only rest 'in the distributional dimensions and substantive effects of these policies' (CLARKE, 1993: 88), but critically in their interrelation with broader economic, social, political and cultural conditions. It is only in this broader context that the overall meaning of LRED can be appraised.

Of course we would not want to throw the baby out with the bathwater. While the U.S. literature in this field has perhaps been preoccupied in recent years with the detailed evaluation of particular LRED policies, there is little doubt that this aspect of the discipline has developed strongly and has made important contributions to our understanding of the practice, and, importantly, the limits, of LRED activity. Indeed, a number of key recent contributions in the U.S. have problematized many of the founding assumptions regarding the effectiveness of LRED activity (see, for example, PETERS and FISHER, 2004). Also, it is apparent that conceptual work alone can become arcane and somewhat detached from practice. In the UK, for example, there has been increasing recognition that recent theoretical contributions around LRED policy have tended to disengage from questions of the material impacts of institutional and policy change (see JONES, 1999: 246). This can create its own tensions, as GRANT (1993: 20) wryly observes: "As is often the case in Britain, the capacity for analysis is not often matched by an ability to bring about change". What is required then is a rebalancing of the focus, and the further development of a conceptual framework which can provide a convincing connection between the profound and the apparently mundane. 


\section{References}

AGLIETTA,M. (1979) A Theory of Capitalist Regulation London. New Left Books.

AGLIETTA,M (1998) Capitalism at the Turn of the Century: Regulation Theory and the Challenge of Social Change New Left Review 41-90

BARTIK,T.J. (2002) 'Evaluating the Impacts of Local Economic Development Policies On Local Economic Outcomes: What Has Been Done and What is Doable?' Upjohn 
Institute Staff Working Paper No. 03-89. W.E. Upjohn Institute for Employment Research

BARTIK,T.J. BINGHAM,R.D. (1995) 'Can Economic Development Programs Be Evaluated?' Upjohn Institute Staff Working Paper No.95-29. W.E. Upjohn Institute for Employment Research.

BEAUMONT,E.F. HOVEY,H.A. (1985) State, local and federal economic development policies: new federal patterns, chaos or what? Public Administration Review 45. 327-32

BINGHAM,R.D. MIER,R. (1993) Theories of Local Economic Development Newbury Park, CA. Sage.

BOYER, R. (1990) The Regulation School: A Critical Introduction Columbia University Press, New York, NY.

BRENNER,R (2007) Structure versus conjuncture: The 2006 elections and the rightward shift New Left Review 43. 33-59

CAMPBELL,J.L. PEDERSEN,O.K. (2006) 'Institutional competitiveness in the global economy: Denmark and the United States' Available at http://brie.berkeley.edu/conf/DKUSA\%20Competitiveness-11.pdf Downloaded June $2^{\text {nd }} 2007$ 
CLARKE,S.E. (1993) The Profound and the Mundane. Urban Geography 14: 78-94.

CLARKE,S.E. (2001) Well, Maybe . . . : Taking Context Seriously in Analyzing Local Economic Development Economic Development Quarterly 15.4. 320-322

CLOKE, P. GOODWIN, M. (1992) Conceptualizing Countryside Change: From PostFordism to Rural Structured Coherence Transactions of the Institute of British Geographers, New Series 17.3. 321-336.

CRUNDEN, R.M. (1996) A Brief History of American Culture North Castle Books. Armonk, New York.

DAVIES,J.S. (2002) Urban regime theory: A normative-empirical critique Journal of Urban Affairs 24.1. 1-17

EISENSCHITZ, A. and GOUGH, J (1993) The Politics of Local Economic Policy Basingstoke. Macmillan

EISENSCHITZ, A. and GOUGH, J. (1998) Theorizing the state in local economic governance. Regional Studies 32. 759-68.

EISINGER, P.K. (1988) The Rise of the Entrepreneurial State Wisconsin. University of Wisconsin Press.

http://mc.manuscriptcentral.com/cres Email: regional.studies@newcastle.ac.uk 
FASENFEST,D. CIANCANELLI,P. REESE,L.A. (1997) Value, Exchange and the Social Economy: Framework and Paradigm Shift in Urban Policy International Journal of Urban and Regional Research 21.1. 7-22.

FLORIDA, R. and FELDMAN, M. (1988) Housing in US Fordism, International Journal of Urban and Regional Research 12, 187-210.

FLORIDA, R. and JONAS, A. (1991) US urban policy: The post-war state and capitalist regulation Antipode 23, 349-384.

FRIEDMAN, (2000) Microregulation and post-Fordism: critique and development of regulation theory New Political Economy 5.1. 59-76

GOODWIN,M. (2001) Regulation as process: Regulation theory and comparative urban and regional research Journal of Housing and the Built Environment 16: 71-87

GOODWIN, M., DUNCAN, S. and HALFORD, S. (1993) Regulation theory, the local state and the transition of urban politics Environment and Planning D: Society and Space $11,67-88$

http://mc.manuscriptcentral.com/cres 41 Email: regional.studies@newcastle.ac.uk 
GOODWIN, M. and PAINTER, J. (1996) Local governance, the crisis of Fordism and the changing geographies of regulation Transactions of the Institute of British Geographers 21, 635-648.

GOODWIN, M. and PAINTER, J. (1997) Concrete research, urban regimes and regulation theory, in Reconstructing Urban Regime Theory (Ed., Lauria, M.), Sage, Thousand Oaks, CA, pp. 13-29.

GORDON, C. (1998) Why No Corporatism in the United States? Business Disorganization and its Consequences Business and Economic History 27. 1. 29-46

GRANT, D.S. Wallace, M. and Pitney, W.D. (1995) Measuring State-Level Economic Development Programs, 1970-1992 Economic Development Quarterly 9. 2. 134-145.

GRANT, W (1993) Business and Politics in Britain Macmillan. Basingstoke

HARVEY, D. (1985) The Urbanisation of Capital Blackwell. Oxford

HARVEY, D. (1989) From managerialism to entrepreneurialism: the transformation of urban governance in late capitalism. Geografiska Annaler 71B. 3-17.

HAY, C. (1995) Re-stating the problem of regulation and re-regulating the local state Economy and Society 24.3. 387-407. 
HENDRICKSON, K. (2004) Bush and the Cities: Urban politics with a moral touch Policy Review 126, August/September

IMMERGUT, E. (1992) 'The Rules of the Game: The Logic of Health Policymaking in France, Switzerland, and Sweden' In Steinmo, S., K. Thelen and F. Longsstreth (Eds.), Structuring Politics: Historical Institutionalism in Comparative Analysis Cambridge, MA: Cambridge University Press.

JENSON,J. (1989) Paradigms and political discourse: legislation in France and the United States before 1914. Canadian Journal of Political Science 22, 235-58.

JENSON,J. (1990) Representations in crisis: the roots of Canada's permeable Fordism. Canadian Journal of Political Science 23, 653-83.

JENSON,J. (1993) Naming nations: making nationalist claims in Canadian public discourse. Canadian Review of Sociology and Anthropology 30, 337-58.

JESSOP, B. (1990) Regulation theories in retrospect and prospect. Economy and Society $19,153-216$.

JESSOP,B. (1997) A neo-Gramscian approach to the regulation of urban regimes. In Lauria, M.,editor, Reconstructing urban regime theory, London: Sage, 51-73. 
JESSOP,B. (2002) The Future of the Capitalist State Cambridge. Polity Press.

JESSOP,B. PECK,J. (1999) Fast policy/local discipline: the politics of time and scale in the neo-liberal workfare offensive Mimeo, Department of Sociology, University of Lancaster.

JESSOP, B., PECK, J. and TICKELL, A. (1999) Retooling the machine: economic crisis, state restructuring and urban politics. In JONAS, A. and WILSON, D., editors, The urban growth machine, New York: SUNY Press, 141-59.

JONES,M. (1999) New Institutional Spaces. London. Jessica Kingsley.

KANTOR,P (2007) Globalization and the American model of urban development: making the market Revue électronique consacrée à l'analyse interdisciplinaire desv illes et du fait urbain No.1

KING, D. S. (1992) 'The Establishment of Work - Welfare Programs in the United States and Britain: Politics, Ideas, and Institutions' In Steinmo, S., K. Thelen and F. Longsstreth (Eds.), Structuring Politics: Historical Institutionalism in Comparative Analysis Cambridge, MA: Cambridge University Press. 
KIRBY,A. (1985) Nine fallacies of local economic change Urban Affairs Quarterly 21. 207-20

KRINSKY,J. (2007) The urban politics of workfare: New York City's welfare reforms and the dimensions of welfare policy making Urban Affairs Review 42.6. 771-798

KRINSKY,J. (2006) The dialectics of privatization and advocacy in New York City's workfare state Social Justice 33.3. 158-174

KRINSKY,J. REESE,E. (2006) Forging and sustaining labor-community coalitions: The workfare justice movement in three cities Sociological Forum 21.4. 623-658

LEHNE,R. (2006) Government and Business: American Political Economy in Comparative Perspective Washington. CQ Press.

LIPIETZ,A (1987) Mirages and Miracles: The Crises of Global Fordism London. New Left Books.

MOLOTCH,H. (1991) The political economy of urban growth machines Journal of Urban Affairs 15.29-53

PAINTER, J. and GOODWIN, M. (1995) Local governance and concrete research: Investigating the uneven development of regulation Economy and Society 24, 334-356. 
PECK, J. and TICKELL, A. (1992) Local modes of social regulation? Regulation theory, Thatcherism and uneven development Geoforum 23.3. 347-363

PECK, J. and TICKELL, A. (1995) The social regulation of uneven development:

'Regulatory deficit', England's South East and the collapse of Thatcherism Environment and Planning A, 27, 15-40.

PETERS,A. FISHER,P. (2004) The failures of economic development incentives Journal of the American Planning Association 70.1. 27-37

PRIOR,A. (2005) UK Planning Reform: A Regulationist Interpretation Planning Theory \& Practice 6.4. 465-484

PURCELL,M. (2002) The state, regulation, and global restructuring: reasserting the political in political economy Review of International Political Economy 9.2. 298-332

REESE,L.A. FASENFEST,D (1997) What works best? Values and the evaluation of local economic development policy Economic Development Quarterly 11.3. 195-207

REESE,L.A. ROSENFELD,R.A. (2001) Yes, But . . . : Questioning the Conventional Wisdom About Economic Development Economic Development Quarterly 15.4. 299-312 
REESE,L.A. ROSENFELD,R.A. (2004) Local economic development in the United States and Canada: Institutionalizing Policy Approaches American Review of Public Administration 34.3. 277-292

TICKELL, A. and PECK, J. (1995) Social regulation after Fordism, Economy and Society 24. 357-386.

TROGEN,P. FEIOCK,R. (1996) "Public Policies and Economic Growth: Stretching the Public Dollar." Paper presented at the Annual Meeting of the American Society for Public Administration

VALLER,D. WOOD,A. NORTH,P. (2000) Local governance and local business interests: A critical review Progress in Human Geography 24.3. 409-428

WIEWEL,W. TIETZ,M. GILOTH,R. (1993) 'The economic development of neighbourhoods and localities' Chapter 4 in R.D.BINGHAM and R.MIER (eds) Theories of Local Economic Development Newbury Park, CA. Sage. 80-99.

WILSON,J.J. (1999) 'An institutionalist take on state activism in economic development: A theoretical system' International Journal of Economic Development 1.3. 1-29. Available at: http://www.fsu.edu/ spap/archive/symposium/WILSON.pdf (Downloaded March 1st 2007) 